\title{
Hvad gør de med faglighed og køn? \\ - interview med studerende på et humanistisk studium
}

Af Susanne V. Knudsen

Hoordan er fag og faglighed relatevet til konnede motivationer? Spørgsmailet diskuteres ved at afdakke, omfortolke og opløse de binare par forskning-undervisning, selvstendighed-skolegørelse.

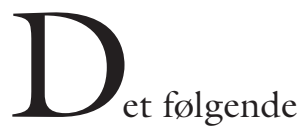

bygger på en nærlæsning af, hvad studerende $\mathrm{i}$ interview siger om fag og faglighed på et humanistisk universitetsstudium. Faget er nordisk. I daglig universitetstale omtales faget i flæng som nordisk og dansk. Fagets genstandsområde er de nordiske sprog. Nordisk er opdelt i forskellige discipliner: Litteratur, sprog, kultur og medier, videnskabsteori, norsk og svensk samt middelalder. Som baggrund for fortolkningerne om fag og faglighed ligger udskrifter af interview med kvinder og mænd på overbygningsuddannelsen samt grund- og bachelorudddannelsen. ${ }^{1}$ Interviewene viser mange nuancer og indbyrdes forskelle og ligheder i forståelser, opfattelser og holdninger til fag og faglighed blandt kvinder og mænd. Det, som kan præsenteres i denne artikel, er løsrevne citater og selektive indblik i fortolkninger, der i vid udstrækning undlader konteksten i såvel interviewene som fortolkningerne.

Metodologisk tager jeg i artiklen afsæt i 
fag og faglighed og herudfra anskues, hvordan motivationer knyttes til henholdsvis kategorien kvinde og kategorien mand (Rittenhofer 1995). Til forskel fra mange undersøgelser af køn og uddannelse, der analyserer generelle forhold i de højere uddannelser og forskningen, går jeg i denne artikel specifikt ind $i$ et fag og undersøger, hvad de studerende siger om fag og faglighed, og hvordan udtalelser om fag og faglighed i mine fortolkninger viser noget om køn og læreprocesser.

\section{FORTOLKNINGSRAMME}

Teoretisk er jeg overordnet inspireret af social konstruktivisme (Søndergaard 1996, Bruner 1998). Mere specifikt anvender jeg en poststrukturalistisk teori og forskning, der interesserer sig for "det, der er tilbage efter, at de systematiske kategoriseringer er udført” (Lather 1992, 90) og det anderledes, hvor "det usædvanlige kan bidrage til synliggørelsen af det sædvanlige” (Søndergaard 1996, 16).

Patti Lather skriver i sin bog Getting Smart om blandt andet poststrukturalismer i flertalsformer og som diskurser (Lather 1991). Hermed inspirerer hun til en forståelse af, at “ismer" bliver anvendt på mangfoldige måder og tager farve efter de forskellige situationer og kontekster, som de indgår i. Om det postmoderne samfund skriver hun, at det er en både-og-verden, der er fuld af paradokser og usikkerhed. Det er karakteriseret ved "mangfoldigheder", "flertydigheder" og "flerstemmig kompleksitet" (Lather 1991, XVI). Kvinder og mænd udfolder sig i det postmoderne samfund mangfoldigt og modsætningsfyldt.

Med reference til franske poststrukturalister skriver Patti Lather, at interessen for "det der er tilbage" ligger i at undersøge usynliggørelse og at være mistænksom overfor dikterede meninger (Lather 1992, 90). ${ }^{2}$ Videre skriver hun, at poststrukturalistiske positioner udfordrer til en undersøgelse af, hvad der gør en diskurs magtfuld. ${ }^{3}$
Patti Lather nævner tre skridt, som jeg ser som led i forskerens fortolkningsprocesser. Det første skridt er at identificere binariteter. Som andet skridt kan forskeren vende op og ned på disse binariteter ved eksempelvis at fortælle dem omvendt, således at negative bliver vendt til positive positioner. Det tredje skridt er at gøre begreber og positioner mere flydende (Lather 1992, 96).

I forlængelse af Patti Lathers overvejelser vil jeg analysere udtalelser fra studerende på overbygnings-, grund- og bacheloruddannelsen ud fra de forskelle i studiesituationen, hvor de specialestuderende er ved at være færdige med nordisk, mens de studerende på grund- og bacheloruddannelsen befinder sig på andet år af deres studium på nordisk.

Forskellene vil her blive anvendt til at identificere binariteter i udtalelser fra henholdsvis specialestuderende og studerende på grund- og bacheloruddannelsen. I første omgang sker det gennem en afdækning af typiske mønstre, hvor del- og helhedsprocesser bliver sat i spil med hinanden i mine systematiseringer af interviewmaterialet. Det vil jeg gøre ved at citere og parafrasere udtalelser fra udvalgte studerende og ved at se disse udtalelser i sammenhæng med, hvad de studerende generelt udtaler om det tema, som jeg er i gang med at fortolke. Ekstreme eksempler inden for binariteterne blandt de specialestuderende bliver fremdraget. De specialestuderende bliver hermed fortrinsvis anvendt til at identificere binariteter. Interview med studerende på grund- og bacheloruddannelsen inddrages til at belyse 'det anderledes' med henblik på at se, om de, som Dorte Marie Søndergaard har vist i sin afhandling, kan bidrage til synliggørelsen af det sædvanlige. Afslutningsvis vil jeg vende op og ned på binariteter og gøre dem mere flydende, således at de måske kan åbne for tanker og adfærd til glæde for begge køn. 


\section{FORSKNING OG UNDERVISNING}

De specialestuderende udtaler sig generelt positivt om det faglige niveau og roser forskningen på nordisk. Specielt bliver de litterære områder og forskningen i litteratur fremhævet. I et gruppeinterview med tre mænd udtales samstemmende, at der er "sprog- og litteraturfløjene", og at der finder en konkurrence sted mellem disse fløje. De diskuterer, hvorvidt der er mest prestige i litteratur og kommer frem til, at litteratur er mere væsentligt at beskæftige sig med end sprog, men at sprog er nødvendigt at have med på trods af, at det er sekundært i forhold til litteratur. Disse mænd har valgt at skrive litterære specialer. I et interview med to kvinder siger den ene kvinde, at litteratur har højere status end sprog, og hun underbygger sin udtalelse med, at langt flere studerende vælger at arbejde med litteratur i deres specialer. Hertil replicerer den anden kvinde, at hun ikke har indtryk af, at der er tale om høj og lav status for henholdsvis litteratur og sprog, og hun argumenterer med, at det derimod handler om, hvor den studerende ud fra sin interesse har placeret sig. Hun har skrevet sit speciale i et litterært område, hvorimod den kvinde, som taler om litteraturens højere status, har skrevet et speciale inden for det sproglige område.

Sammenlignes disse udtalelser med de 97 registrerede specialeskrivere i 1997-98, vælger 60 studerende et speciale inden for det litterære område. Gruppeinterviewet med de to kvinder viser, at den kvinde, som har valgt at skrive sit speciale inden for det litterære område, er den, som er mest sikker på, at hun har valgt et godt specialeområde.

\section{LITTERATURENS HøJE STATUS}

Der kan være og er flere individuelle forklaringer at hente blandt de to kvinder med hensyn til deres forskellige holdninger til faget, men her vil jeg søge at fastholde betydningen af litteraturens høje status på nordisk. Denne status underbygges af interview med de andre specialestuderende. Når de taler om fag, taler langt de fleste om litteraturen i faget. Denne dominans underbygges af, at de på overbygningsuddannelsen har fået tilbudt flest litterære emner og flest litterære A-emner, der har ekstern censur og bedømmes efter 13-skalaen. De fleste undervisere med forskningsforpligtelse er orienteret mod litterære områder. Der har været en vis træghed i ansættelsen af undervisere på sprog. Dog er der inden for de sidste par år blevet ansat lektorer inden for sprog, således at denne disciplin har fået øget antallet af undervisere med forskningsforpligtelse. ${ }^{4}$

Om valget af disciplinen litteratur siger de studerende, at der også skal vælges forfattere inden for "modebølger". I interviewene fortæller de studerende om valg af forfattere som St.St. Blicher, J.P. Jacobsen og Sophus Claussen. Omvendt kan en kvindelig studerende fortælle, hvordan hun er stødt mod normer for litterær kvalitet på nordisk. Hun refererer en underviser for at have udtalt, at kvindelige forfattere ikke besidder litterær kvalitet.

Samme kvindelige studerende beretter om, at hun på studiet har tilbudt at holde et oplæg om en kvindelyriker, og at hun her er stødt mod, hvad jeg vil kalde normer for videnskabelig kvalitet på nordisk. I stedet for at koncentrere sig om genren foretrak hun at inddrage en biografisk læsning af forfatterskabet. Hendes vurdering i interviewet er, at hun af underviseren blev sat på plads med, at "det var ikke det, som det skulle handle om, det var hendes digte. Uafhængigt af hendes liv". Her mener jeg, at hun fortæller, at hun ikke alene er stødt mod normer for litterær kvalitet, der ligger inden for, hvad jeg vil kalde en litterær kanon af mandlige forfattere, men også mod normer for videnskabelig kvalitet, hvor biografiske studier ligger uden for den litterære faglighed, mens tekstorientering er en faglighed, der godkendes på nordisk. Eller sagt i litteraturdisciplinens termer: den bio- 
grafiske metode er uacceptabel, hvorimod en nykritisk eller semiologisk orienteret metode er ønsket.

Teoriernes betydning i såvel de studerendes specialeskrivning som i de ansattes forskning og undervisning bliver synlige $\mathrm{i}$ interviewene; men anvendelsen af dem skaber debat mellem de interviewede. I et gruppeinterview med tre mandlige studerende fortælles, at det gode speciale er "tungt teoretisk".

Flere af de interviewede nævner den franske filosof Jacques Derrida som en teoretiker, der bør med i specialet. Om brugen af ham siger en kvinde: “... ham har jeg det ikke så godt med, og det har min vejleder, og jeg har sagt, det der, den halve side, hvis det kan holde vand, så vil jeg ikke røre mere ved ham." Vejlederen har accepteret den kvindelige specialeskrivers valg ved i kvindens udlægning at sige: "Fint nok, det slipper du så for." Denne kvinde kan siges at have fundet sit balancepunkt ved at forhandle med sin vejleder om at minimere specialets teoretisk abstraktionsniveau, sådan som reduktionen af Derrida's teorier indicerer.

Flere kvinder end mænd udtaler, at de har problemer med at tilpasse sig de teoretiske ambitioner, som de specialestuderende uden undtagelser mener at have gennemskuet hører til på nordisk. I et gruppeinterview med tre kvindelige studerende beretter de på skift om, hvordan det teoretiske niveau på nordisk har ført til faglig usikkerhed og har ført dem ind i faglige kriser. En af kvinderne siger, at “jeg har virkelig făet sådan en følelse gennem studiet af, at jeg ikke er egnet til forsker ... De der høje teorier kan jeg slet ikke klare". En af de andre kvinder supplerer hende, idet hun siger: "Det du siger med tab af faglig selvsikkerhed, at den faglige selvtillid ryger ned er altså en af grundene til, at når jeg har skrevet mit speciale, så vil jeg ikke skrive opgave mere."

Betydningen af at have valgt litteratur som sit specialeområde sammen med nyere

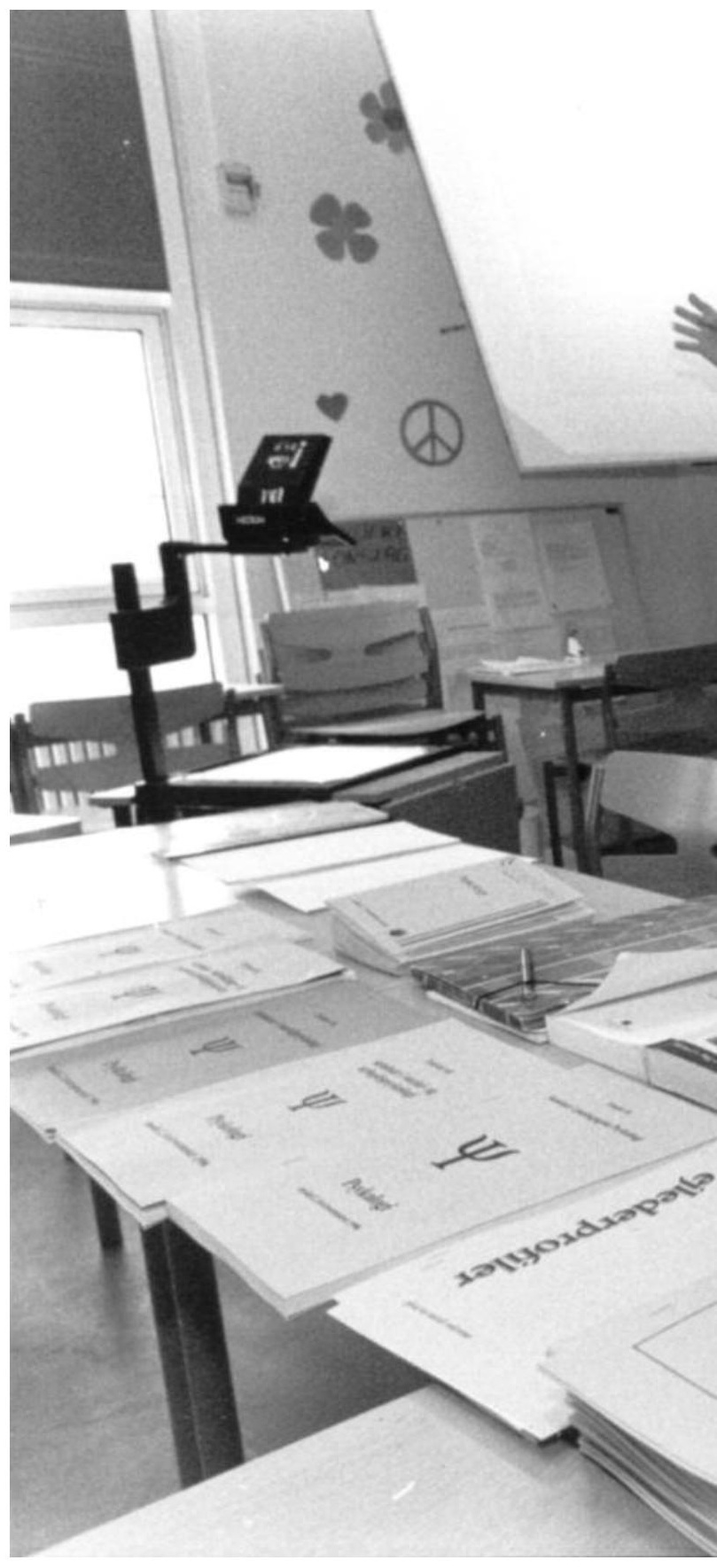




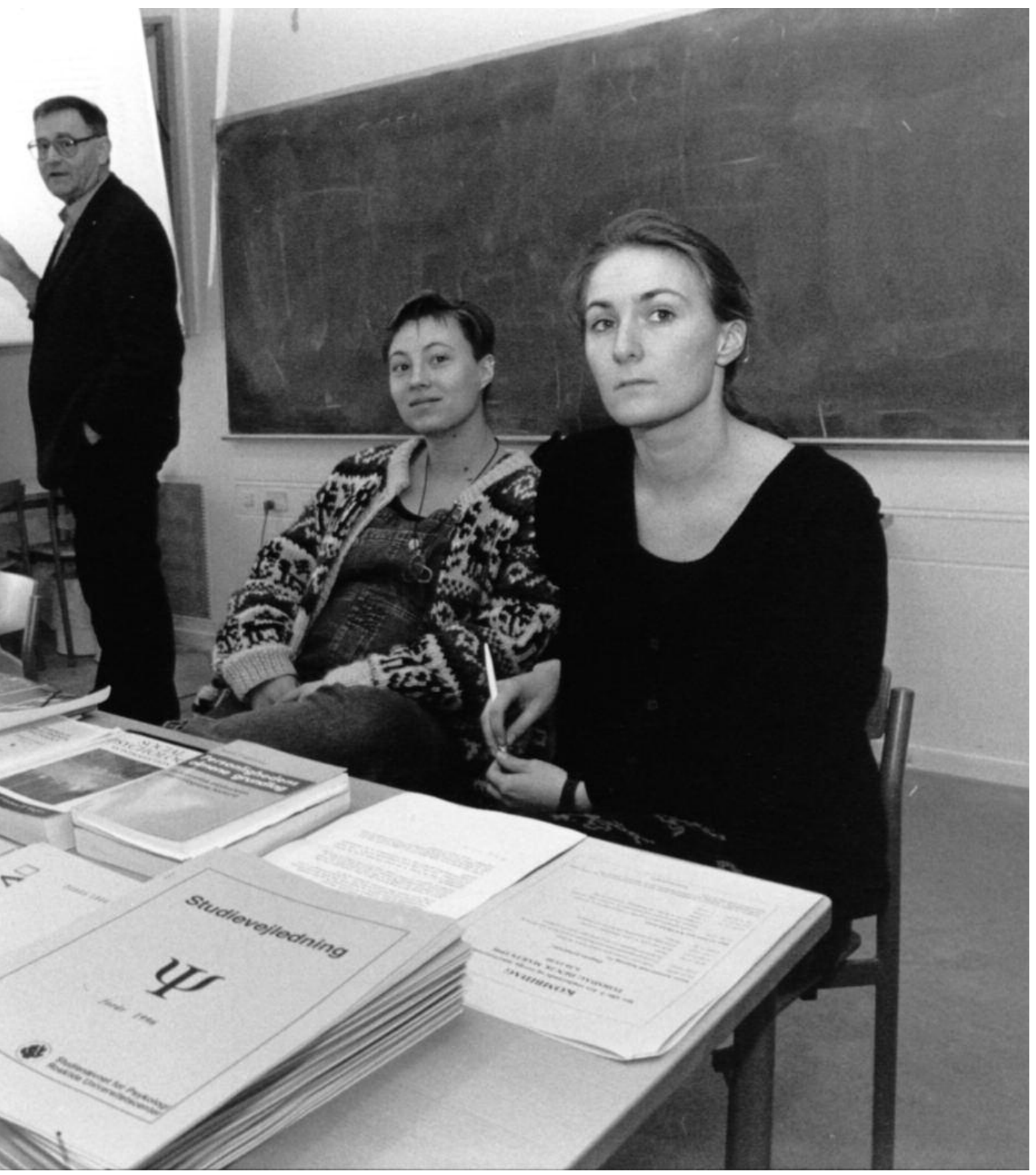


teorier aftegner sig i det skriftlige spørgeskema, hvor vi har bedt de specialestuderende om at afkrydse Ja, Nej eller Måske til et ph.d.-forløb. Studerende med valg af litteratur inden for tidens litterære modebølger på nordisk, fx J. P. Jacobsen, og teori inden for tidens filosofiske trendsættere, $\mathrm{fx}$ Jacques Derrida, sætter hyppigst kryds i Ja til et ph.d.-forløb.

Litteratur på nordisk får sin magtfuldhed fra flere sider. Der er flest undervisere inden for litteratur, og disse undervisere lægger vægt på de forskningsmæssige og teoretiske sider af faget ifølge de specialestuderende. Undervisningen og forskningen er koncentreret om en litterær kanón af mandlige forfattere og mandlige teoretikere, ligesom undervisningen og forskningen i litteratur på nordisk i overvejende grad bliver varetaget af mandlige undervisere. 5

\section{DEN INDFORSTÅEDE TALE OM FAGLIGHED}

De studerende, der har sat kryds i Ja og Måske til et ph.d.-forløb, og som i interviewet er tilbøjelige til at skifte fra Måske til Ja taler indforstået om fagligheden. De taler om faglig dygtighed hos underviserne, og de taler om en sammenhæng mellem forskning og undervisning. En mandlig studerende udtrykker eksempelvis sin begejstring for den "nøgne nysgerrighed" og omtaler "de studerende som udforskende". Han synes godt om "detaljeret fordybelse". I et gruppeinterview med mandlige studerende fremhæves "evnen til at sortere" og at "søge ind i sammenhænge". Sådan som jeg tolker disse mænd, giver de udtryk for, at fagligheden i specialet viser sig gennem en evne til at tænke snævert, således at stoffet indordnes specialets tese(r). Med en enkelt undtagelse har disse mandlige studerende valgt at skrive speciale inden for et litterært emne, og den mandlige 'undtagelse' skriver et speciale, der bygger på sproglige teorier, som han afprøver på litterære værker.
En kvindelig studerende udtaler, at hun har hørt og læst, at kvinder har "en bred indgangsvinkel", og at de ser på de "store sammenhænge", hvorimod mænd går mere specifikt til værks. Hun understreger, at denne forskel på kvinder og mænd kan hun nikke genkendende til. Hun vil hellere brede sig og se store sammenhænge end fordybe sig i detaljer. En anden kvinde taler om, at hun finder det væsentligt at have "et vist overskud" som specialeskriver og forsker. Disse kvinder har valgt at skrive speciale inden for sprog og middelalder. Undtagelsen blandt de interviewede kvinder udtaler, at hun foretrækker den analytiske fordybelse i litterære tekster, hvor hun kan bevæge sig "fra de mindste enheder og op".

I interviewene gør kvinderne, som sætter kryds i Ja- og Måske-felterne en del ud af, hvor vigtigt det er at have vist sig som "selvstændig". Denne selvstændighed indeholder blandt andet "engagement", "at turde noget", at være "selektiv", "kritisk" og “opsøgende".

Med sådanne udtalelser om faglighed vurderer jeg, at de studerende har accepteret og integreret normerne for den faglige forskning på nordisk. Både kvinder og mænd, der kan tænke sig et ph.d.-forløb på nordisk, taler generelt om regler for videnskabelighed som fx fordybelse og overblik. De finder ingen grund til at give eksempler $\mathrm{i}$ interviewerne, og kun når interviewerne beder om eksempler, bliver de præsenteret, men uden at de finder det nødvendigt at argumentere for, at netop disse eksempler på forfattere og teorier trækkes frem. De taler indforstået accepterende om fordybelse og overblik. Men mænd og kvinder fokuserer på forskellige perspektiver i deres omtale af fagligheden, og her tolker jeg, at mands- og kvindesiden udviser forskellige motivationsmønstre. Motivationerne på mandssiden ligger i stikord som det detaljerede, fordybelsen, snæverheden og nysgerrigheden, hvor de på kvindesiden ligger i stikord som det mangfoldige, overblikket, bredden og selvstændigheden. 


\section{DEN KRITISKE TALE OM FAGLIGHED}

De studerende, der har sat kryds i Nej i spørgeskemaet og i interviewene siger $\mathrm{Nej}$ eller Måke med hældning til et nej til et ph.d.-forløb, udtrykker sig kritisk og med distance til fagligheden på nordisk. Kritisk siger en kvindelig studerende: “... mit hjerte banker altså ikke for litteraturteori, det banker for litteratur." En anden kvindelig studerende kritiserer den "manglende praksis", og at studiet er "langt væk fra noget jordnært". Med distance siger hun: "Det der danskstudie bygger bare på teori, hvad andre har sagt."

Om teorien siger nogle mandlige studerende med kritisk distance, at den er "bejlende til filosofi" og "meget svavende". Om faglighedens indhold siger de, at det er "meget tungt teoretisk" og har et "meget højt forudsætningsniveau". Såvel de kvindelige som de mandlige studerende giver mange konkrete eksempler på, hvad de er utilfredse med i specielt undervisningen i litteratur.

Min vurdering er, at disse kvinder og mænd er både fælles om og forskellige i deres beskrivelser af fagligheden. De er alle kritiske over for formidlingen af teorierne på studiet. Men kvinderne tager skarpere afstand fra anvendelsen af teorierne, end mændene gør. De mandlige studerende understreger "meget", hvad de mener om fagligheden: "meget tungt teoretisk", "meget svævende" og "meget højt forudsætningsniveau". De kvindelige studerende udtaler sig om mangler ved studiet: "manglende praksis" og mangler i undervisningen: "langt væk fra noget jordnært". Tonefaldet spiller her en rolle. Mændene anvender et tonefald, så de i deres kritik og distance også lyder, som om de er fascineret af den høje faglighed i undervisningen, mens kvinderne skifter mellem et skarpt anklagende og et beklagende tonefald, når de kritiserer fagligheden i undervisningen.

Både de kritisk udtalende mænd og kvinder viser sig, sådan som jeg fortolker dem, at lægge vægt på at få undervisningsmæssi- ge færdigheder i studiet, og at de er mest interesseret $\mathrm{i}$ anvendelsen af primærkilder som litteratur og medietekster. Flere af disse studerende er kritiske over for den undervisning, som de er blevet præsenteret for på nordisk, og de mener, at forskningen er vægtet højere end undervisningen i specielt de litterære discipliner.

\section{EKSTREME EKSEMPLER}

Binariteterne litteratur og sprog, teori og primærkilder samt den indforståede og den kritiske tale om fagligheden drejer sig overordnet om modsætningsparret forskning og undervisning. I de individuelle interview fremstår Mikael og Helle som ekstreme eksempler på henholdsvis den, der i interviewet hælder til et Ja til et ph.d.-forløb og har orienteret sig mod forskningen i studiet, herunder fordybelsen i teorier, som taler indforstået om fagligheden - og den, der siger Nej til et ph.d.-forløb, kritiserer den manglende anvendelsesorientering i studiet og distancerer sig fra formidlingen af teorier i undervisningen. De kan vise, at karriere er knyttet til kategorien mand og barriere til kategorien kvinde (Rittenhofer 1995, Søndergaard 1996).

Mikael har efter 2 1/2 års specialeskrivning afleveret sit speciale. Helle er på tidspunktet for det individuelle interview i gang med at læse sig ind på og afgrænse sit specialeemne. Hun fortæller, at hun "kun" har råd til at arbejde med specialet i $1 / 2$ år.

I interviewet redegør Mikael for sit speciales teser og processer på sådanne måder, at han viser sin interesse for teoretiske problemstillinger. Han kan teoretisere på et højt filosofisk og fagligt niveau, og han har taget teorier i anvendelse, der viser interessen for at integrere filosofi og litteratur på nordisk. Han kan fordybe sig i en problemstilling og blive i den, indtil den løser sig op for ham i form af nytænkende forskning. Han kan forholde sig analytisk og fortolkende til tekstdetaljer. 
Helle har i en selvkritik af egen uformåenhed overfor teorikravene i studiet forhandlet sig frem til, at hun ikke vil være forsker. Hun angiver tre grunde, som sætter sig som barrierer for hende for at blive forsker her og nu:

\section{* “jeg føler mig ikke egnet på grund af vi- denskabeligheden"; \\ * "det akademiske miljø, som jeg synes, er lidt træls"; \\ * "det er svært at kombinere med familie".}

Helles manglende egnethed for videnskabelighed, fortæller hun, ligger $i$, at hun ikke kan og vil leve op til de teoretiske krav, sådan som de stilles på nordisk. Undervejs $\mathrm{i}$ studiet har hun i mødet med teorierne mistet $\sin$ faglige selvtillid. Derimod vil hun kunne motiveres til at interessere sig for teorier, hvis de bliver præsenteret mere anvendelsesorienteret, sådan som hun har set teorierne blive praktiseret på et andet nordisk universitetet.

Såvel Mikael som Helle fortæller om, hvordan de i løbet af universitetsstudiet har fåt lave karakterer ved eksamener. Men hvor Mikael kan fortælle om, at han er blevet opfordret til at fortsætte, fordi "du kan noget andet”, så har Helle ikke fået respons på sine opgaver $\mathrm{i}$ anden form end et tal på en tavle. Denne respons har hos hende afsat et indtryk af, at hun er usynlig på stedet. Styrken til at gennemføre specialet får hun i en speciale- og responsgruppe, som hun selv har taget initiativ til at igangsætte.

Hvor Helles drivkraft er samarbejdet med andre i en responsgruppe, har Mikael foretrukket at arbejde for sig selv. Når han fra undervisere på nordisk har fået at vide, at han kan noget andet, så har han gennem intense selvstudier søgt at finde ud af, hvad denne anderledeshed går ud på. I de første studieår læste han "24 timer i døgnet”. Når han har været til undervisning og har hørt en forelæser, hvis pointer han ikke har forstået, så har han studeret vedkommendes kilder og teorier, indtil han mente at have forstået dem. Ud fra sådanne beskrivelser i interviewet vurderer jeg, at han er kommet dybt ind i det faglige indhold på nordisk, og at han har accepteret fagligheden ved dels at tage den til sig som sin egen, dels at udfordre den. Han har levet op til selvstændighedskulturen ved sin anderledeshed og ved sin indædte biden sig fast som en bulldog.

Heroverfor har Helle i sit speciale foretrukket at arbejde sammen med andre. Studiemiljøets betydning og samværet med de andre studerende i en speciale- og responsgruppe spiller en stor rolle for hende. Mikael har derimod foretrukket at arbejde alene og selv at løse de faglige problemer, som han i løbet af studiet er stødt ind i. Helle kritiserer studiemiljøet for at være "upersonligt", at være et sted hvor det går ud på "at tromle hinanden" og at være "den, der lukkede institution". Som betingelse for trivsel stiller hun, at der skal være flere kvinder ansat, at studiemiljøet skal være "mere menneskeligt" og at "man skal bakke hinanden mere op". Hvis videnskaben bliver mere relateret til det virkelig liv og i højere grad bygger på samarbejde, mener hun, at studiemiljøet vil ændre sig og åbne sig, også for en kvinde som hende. Sådanne krav kommer Mikael ikke ind på i interviewet, og da han eksempelvis bliver spurgt om, hvorvidt han er blevet opfordret til at søge et ph.d.-stipendium svarer han, at han selv har taget initiativ til en samtale med sin vejleder om et muligt forskningsprojekt.

Med Helles familiesituation på interviewtidspunktet med to små børn, som hun er alene med i dagligdagen, og som gør, at hun må arbejde "fuldtids inden for deltidsrammer", når børnene er raske, kan hun have ret i, at det kan være svært at kombinere forskning og familie. Mikael har ikke sådanne forpligtelser, da han ingen børn har, således at han $\mathrm{i}$ sin specialeskrivning har kunnet arbejde 'overtid inden for fuldtidsrammer'. Han har brugt $21 / 2$ år på sit speciale. Helle har på grund af familiens økonomi med studiegxld ikke råd til sam- 
menlagt at anvende mere end $1 / 2$ år på sit speciale, siger hun.

Med Mikael og Helle som ekstreme eksempler viser en karriere sig at bygge på en mand, der kan og vil bruge sin tid ud over studienormeringer. Han skal have lyst til at sætte sig ind i teorier og have lyst til at fordybe sig i detaljer. Han skal have et stærkt ego. Han har ingen børn, og han har en hustru, der ifølge hans udtalelser affinder sig med, at "hjemmefronten er blevet nedprioriteret" i en årrække med hans specialeskrivning.

Barriererne findes hos en kvinde, der vil studere inden for rum og rammer, hvor der også er plads til at have børn og familieliv. Hun har lyst til at sætte sig ind i anvendelsesorienterede teorier. Hun svinger mellem sikkerhed på, hvad hun vil og ønsker sig af fagligheden og usikkerhed over for egen faglig formåen. Hun ønsker såvel et socialt som et fagligt liv.

Sådan som nordisk fungerer på interviewtidspunktet i foråret 1998 falder Mikaels udtalelser mest i tråd med fag- og faglighedsforståelsen samt med en kommende forskningskarriere. Hvor Mikael i sit studium har orienteret sig mod forskning, er Helle i sit krav til mere praksis i studiet orienteret mod, hvad undervisningen har givet hende til hendes kommende tilværelse som underviser. Med denne adskillelse i interesser i forskning og undervisning, er der med Mikael og Helle som eksempler efter min vurdering tale om en kønssegregation: til forskning knyttes kategorien mand og til undervisning kategorien kvinde.

\section{DE ANDERLEDES}

Blandt de specialestuderende står Helle samtidig som en meget anderledes person med sine udtalelser. Hun lægger på interviewtidspunktet vægt på undervisningen og formidlingen. Bag denne orientering ligger en proces med oplevelser af afmagt over for det teoretiske niveau på nordisk. Måske har hun på den baggrund også forhandlet sig frem til et speciale, der ligger inden for området "andet". Men også Mikael er med sit specialevalg og sin teoretiske satsning udtryk for en meget anderledes person på nordisk. At han overhovedet satser på et ph.d.-forløb kan betragtes som at bryde med det sædvanlige for en studerende på nordisk, al den stund at der kun er få ph.d.stipendier såvel på det pågxldende som de øvrige danske universiteter og højere læreanstalter med forskning i nordisk.

I temaerne til interview blandt de studerende på grund- og bacheloruddannelsen bliver de under stikordet "studiet" spurgt om, hvilke kompetencer, de mener, at de opnår gennem studiet. De fleste studerende svarer, at de i de første tre semestre har fået kompetencer inden for litteratur til at varetage deres kommende arbejde som undervisere. Derimod er disse studerende ikke opmærksomme på, om de har erhvervet sig forskningskompetencer. Den litterære orientering på nordisk er de fleste studerende tilfredse med, idet den svarer til, hvad de på forhånd har forventet af studiet. Karakteristisk er, at de satser på undervisning efter uddannelsen uden for universitetet, og at de ikke ser muligheder i et ph.d.-forløb på nordisk.

De anderledes blandt de studerende på grund- og bacheloruddannelsen findes $\mathrm{i}$ den ene yderpol i denne undersøgelse blandt de studerende, der ønsker sig et ph.d.-forløb. Disse studerende ønsker sig mere forskning og flere teorier i undervisningen. De fortæller, at de i deres orientering mod en forskertilværelse vælger sig en fremtid uden succes og uden for, hvad der er "hot" i tiden. Sådan formulerer de to mandlige studerende, der på interviewtidspunktet siger sig henholdsvis interesseret og måske interesseret i en forskertilværelse, sig om den manglende status, der ligger i at satse på at blive forsker på nordisk. Den kvindelige studerende, som i spørgeskemaet har sat kryds i Ja til et ph.d.-forløb er i interviewet $\mathrm{i}$ tvivl om, hvorvidt hun alligevel ønsker et ph.d.-stipendium, idet hun da 
vil blive knyttet til et miljø, hvor hun har iagttaget en konkurrence, som hun ikke bryder sig om.

De tre ovennævnte studerende er orienteret mod litteratur. Hun er i sit studium optaget af "detaljen" og "det tekstnære", siger hun $\mathrm{i}$ interviewet. Her må hun siges at anvende begreber, som flere specialestuderende mænd end kvinder bruger for at motivere deres interesser i studiet. En enkelt kvinde blandt de specialestuderende skiller sig her ud og siger, at hun orienterer sig mod “detaljen" og "fordybelsen". Disse to sidstnævnte kvinder adskiller sig i deres udtalelser fra de kvinder, som vi har interviewet. Det sædvanlige hos specialestuderende kvinder og kvinder på grund- og bacheloruddannelsen kan dermed siges at pege i retning af det mangfoldige og overblikket, sådan som flertallet af de specialestuderende kvinder, der taler indforstået om fagligheden, udtrykker sig om deres interesser i studiet.

Kvinden på grund- og bacheloruddannelsen fortæller endvidere, at det er muligt, at hun vil gå i gang med et teoretisk orienteret forskningsprojekt. Også de mandlige studerende, der er interesseret og måske interesseret i en forskertilværelse, udtaler, at de vil være orienteret mod teoretiske problemstillinger i en eventuel kommende forskertilværelse.

I den anden yderpol på grund- og bacheloruddannelsen findes de studerende, der i vores materiale udtaler, at de vil forlade studiet. En mandlig studerende ønsker at forlade studiet, fordi han har søgt nordisk for at studere sprog og er blevet skuffet over litteraturens dominans på nordisk. Han kritiserer endvidere nordisk for at være orienteret mod dansk litteratur og at glemme de andre nordiske sprog, norsk og svensk. To kvindelige studerende forlader studiet med begrundelserne, at de finder det for abstrakt og videnskabsorienteret. En af disse kvinder beklager, at hun ikke har været i stand til at prioritere de mængder af læsestof, som hun er blevet præsenteret for, således at hun $\mathrm{i}$ for ringe grad har fået tid til et liv uden for universitetet. Hun fortæller endvidere om, at hun finder, at miljøet er fremmedgørende. Også den mandlige studerende, som forlader studiet, fortæller, at han ikke har kunnet finde ud af at prioritere læsestoffet, og at han oplever sig som meget ensom på nordisk.

De to kvinder, som siger, at de vil forlade studiet, er orienteret mod litteraturen og synes godt om at læse litteratur og roser den kvindelige underviser, som de har haft i litteratur. Men de finder, at studiet, herunder undervisningen i litteraturhistorie, i for ringe omfang kan anvendes $i$ et kommende arbejde som undervisere uden for universitetet.

Disse yderpoler er som billeder på det anderledes med til at belyse det sædvanlige på grund- og bacheloruddannelsen på nordisk. Den store mellemgruppe af studerende takker Nej til et ph.d.-forløb, og de fortæller i interviewene om, at de satser på undervisningen efter uddannelsen og gerne på et gymnasium. Det sædvanlige for disse studerende er at forestille sig en fremtid uden for universitetet.

Da de i interviewet bliver spurgt om, hvilke forskningsmæssige kompetencer de mener at have fàet i studiet, viser svarene, at flertallet ikke er opmærksomme på, hvorvidt de modtager forskningsbaseret undervisning.

\section{SKOLEGØRELSE OG SELVSTÆNDIGHED}

I Selvevaluering omtales skolegørelsen som en beklagelig udvikling på nordisk (Selvevaluering 1996, 1, 26, 33). Den kobles sammen med et masseuniversitet, hvor studierne er effektiviseret i undervisning på store hold og i forkortelse af studietiden. Over for denne udvikling bliver der i selvevalueringen stillet krav om dels at "værne om forskningsfriheden", og at "undervisningen er forskningsbaseret”, dels at motivere de studerende til "selvstudium og selvstændig forskning". I selvevalueringen beklages, at 
de unge studerende taler om "klasser, lektier og frikvarter" og stiller minimale eksamenskrav til sig selv (Selvevaluering 1996, 1).

I interview med en mandlig underviser på nordisk kritiserer han denne skolegørelse. ${ }^{6}$ Han ser skolegørelsen komme til udtryk ved, at de studerende forventer mere af underviseren i form af, at han skal være "forberedt" og holde "foredrag". De studerende forventer, siger han, at underviseren kommer med en plan, og de er ikke vant til at tage stilling til denne plan eller til at tænke i projekter. Det er, som om underviseren skal "formidle et på forhånd givet pensum”. Forklaringen på denne skolegørelse finder han i de studerendes "lange vej gennem institutionerne", hvor de er vant til at blive vejledt, og de er vant til, at de har ret til at stille krav.

Kritiske og selvkritiske udtalelser fra nogle mandlige studerende på grund- og bacheloruddannelsen bærer også præg af, at de mener, at der på nordisk er en beklagelig tendens til skolegørelse. Som en af disse studerende udtaler, så er tendensen, at de studerende betragter studierne som et "job", hvor de kommer til tiden og går hjem for at forberede sig af nødvendighed, men derudover vil have tid til "et liv ved siden af”. I stedet for denne skolegørelse sætter han et studium, der omgiver livet, som "tænder mig fuldstændigt", og som drives af den "dybe lyst og trang".

I et interview med et par kvindelige studerende taler de om skolegørelsen som "det gymnasieagtige", der bliver ringeagtet på nordisk. Ikke desto mindre fastholder de to kvinder, at de forestiller sig en tilværelse - i hvert faldt fald på kort sigt - i gymnasiet. De finder, at deres undervisere sætter lighedstegn mellem "pædagogik, formidling og lavt niveau", mens "et højt niveau" er for dem "deroppe", "langt oppe" og "langt væk".

En debat mellem en underviser og en studerende i instituttets interne blad Vandfanget er på mange måder karakteristisk for den udvikling af positioner, der findes på nordisk, når forskning stilles over for undervisning og selvstæendighed over for skolegørelse. I "Fra studium til uddannelse" takker Jørgen Elbek af efter cirka fyrre år som underviser på nordisk, fordi han ikke ønsker at undervise i "et vist jævnmål” og i "den skoleagtige lærerrolle", hvor han forventes at formidle et stof (Vandfanget 1998, 11-12). I sit indlæg kritiserer han de studerende for ikke at være "medstuderende", der sammen med underviseren søger i sagen, men er blevet "uddannelsessøgende". Sådan som jeg læser hans indlæg er det den forskningsbaserede undervisning, hvor de studerende arbejder aktivt sammen med forskeren, som, han mener, er forsvundet i halvfemserne.

I et interview med et par kvindelige studerende fortæller de, at Jørgen Elbek har kritiseret nordisk for at være blevet en "pigeskole", og at han med den begrundelse har sagt sin stilling op. Under mærket "K" tager en kvindelig studerende til genmæle mod Jørgen Elbeks indlæg med overskriften "HSKDV ... sagde de unge og lod træet fælde! Svar til Jørgen Elbek" (Vandfanget 1998, 12-14). Hun kritiserer ham for ensidigt at se ned på de unge studerendes "indskrænkethed og parasitære" holdning, og med ironi anmoder hun ham om selvkritisk at tænke over, om han er "kommet ud af trit med tiden" i sin opfattelse af forskningen og de studerendes ønsker.

I “Gensvar til K” skriver Jørgen Elbek, at han finder, det er "brugernes øjeblikkelige behov og udfoldelsesmuligheder, der står i centrum", og at de uddannelsessøgende i stedet for "sagsorientering" er orienteret mod "personcentrering" (Vandfanget 1998, 14-15).

Jørgen Elbek kritiserer, at den forskningsbaserede undervisning $i$ form af medstuderende er forsvundet. De studerende er i min fortolkning af Jørgen Elbeks indlæg orienteret mere mod deres kommende erhverv og mod egen identitetsudvikling.

Med de grund- og bachelorstuderendes 
fokus på undervisningen og manglende opmærksomhed på forskningen kan de siges at se på udbyttet af undervisningen som en investering $\mathrm{i}$ en fremtid som undervisere. Elbeks undervisning er utidssvarende og ubrugelig svarer den studerende, der tager til genmæle mod Jørgen Elbeks indlæg. Denne studerendes ønske kan tolkes sådan, at hun kræver af undervisningen, at den skal være nyorienteret og altså i en eller anden forstand være forskningsorienteret, selv om de studerende hverken i debatindlægget eller $\mathrm{i}$ interview med os pointerer forskningsdimensionen.

\section{FORSKNINGSBASERET UNDERVISNING}

Forskningsbaseret undervisning er et ofte debatteret emne på de højere uddannelsesinstitutioner i dagens Danmark, hvor der gives færre bevillinger til forskningsansættelser, mens antallet af studerende er stadigt stigende. På den baggrund kan et modsætningsforhold mellem forskning og undervisning siges at udmønte sig i en stadig større polarisering mellem selvstændighed og skolegørelse. I sammensætningen "forskningsbaseret undervisning" ligger et ideal om, at der på nordisk er tale om en undervisning, der er baseret på forskning. Men hvis forskning? For hvem? Og til hvem?

I debatten på nordisk er der flere definitioner på forskningsbaseret undervisning på spil. Det mest yderliggående krav ligger hos Jørgen Elbek, hvor fokus sættes på forholdet mellem forskeren og de studerende, som jeg vil kalde et mester-lærlinge-forhold, hvor de studerende lærer at forske gennem samarbejde med forskere. Denne betydning af forskningsbaseret undervisning er blevet kaldt for "idealets historiske kerne” (Laursen 1996). Den hører jeg komme til udtryk hos de specialestuderende, når de fortæller om en underviser, som har inddraget dem i sit igangværende forskningsarbejde med en litterær forfatter. Mere generelt fortæller de specialestuderende kvinder om denne kerne, når de taler indforstået om betydningen af selvstændighed.

I den anden ende af skalaen findes den bredeste betydning af forskningsbaseret undervisning, der forekommer, når undervisningen i sit indhold er baseret på forskningsresultater. Heri ligger ikke noget krav om, at underviseren selv skal være forsker. På nordisk bliver denne undervisning varetaget af amanuenser, eksterne lektorer, undervisningsassistenter og studenterundervisere uden forskningsret og -pligt. Kun hvis disse undervisere deltager i møder og konferencer på instituttet, kan de siges at være deltagere $\mathrm{i}$ et forskningsmiljø; men de er ikke af den grund forskere og i hvert fald er de ikke lønnede forskere. Udtalelser fra de studerende på grund- og bacheloruddannelsen tyder endvidere på, at underviserne med og uden forskningsforpligtelse ikke giver indsigt $i$, hvad de forstår ved forskningsbaseret undervisning, og hvordan de mener, at forskningen er til stede i deres undervisning.

\section{BINARITETERNES MAGT}

Fortolkningerne af de studerendes udtalelser på overbygnings- samt grund- og bacheloruddannelsen viser, at de balancerer mellem eller slet og ret vælger side mellem forskning og undervisning og skolegørelse og selvstændighed.

Min opmærksomhed på binariteter og på ekstreme eksempler og de anderledes giver billeder af det sædvanlige og statusgivende på nordisk. Risikoen er imidlertid en valorisering, så der bliver tale om negative og positive poler. På positivlisten står forskning og selvstændighed, mens negativlisten består af undervisning og skolegørelse. Vinderne på denne liste bliver de teoretisk og de litterær orienterede undervisere og studerende, som endvidere accepterer, at der arbejdes med modebølger inden for mandlige forfattere og mandlige teoretikere. Udelukket fra en fremtid som underviser og forsker på nordisk bliver de studerende, 
som lægger deres interesser i arbejdet med primærlitteratur og -tekster, som ønsker anvendelsesorienterede perspektiver lagt ind $\mathrm{i}$ studiet, og som vil have et fritids- og familieliv ved siden af studiet. Så enkelt er forholdene ikke på nordisk, når de studerende udtaler sig og heller ikke i den undervisning, som jeg har observeret (Knudsen 1999, 2000b).

Betragtet ud fra et kønsperspektiv er der kvindelige studerende på nordisk, som foretrækker, at teori og litteratur bliver integreret; men endnu flere kvinder orienterer sig mod den primære litteratur. Der er mænd, som foretrækker arbejdet med primærlitteratur; men flere mænd end kvinder er orienteret mod teorier, der kan integreres i de litterære områder. Nogle kvinder foretrækker at få overblik, mens nogle mænd siger sig interesseret i fordybelsen. Omvendt siger nogle kvinder, at de er orienteret mod fordybelsen, og nogle mænd kritiserer, at de ikke har făet overblik nok i studiet. Nogle kvinder og mænd fremhæver selvstændigheden i studiet, mens andre ikke har noget imod skolegørelsen, hvor de făr hjælp til blandt andet at prioritere læsestoffet og at afprøve, hvordan et stof kan struktureres, når det skal formidles til de andre studerende.

En måde at løse op for binariteterne er at se på forskningsbaseret undervisning som undervisningsbaseret forskning. I den undervisningsbaserede forskning vil anvendelsesperspektivet, som er taget frem som krav fra nogle studerende kvinder, men som studerende af begge køn mener mangler i studiet, blive taget op. Det vil blandt andet betyde, at praksis og senere professionalisme i form af gymnasielærerjob efter uddannelsen kan udfordre underviserne og de studerende til undervejs i studierne at reflektere over, hvad de lærer, hvordan de lærer, og for hvem de lærer på studiet.

Et par mandlige og en kvindelig studerende udtaler, at de i kultur og medier har fundet en disciplin, der på forskellige måder motiverer dem i studiet. De sætter fokus på en disciplin, der ellers er trængt i baggrunden, når litteratur gøres så magtfuld på bekostning af sprog i de studerendes udtalelser. Disciplinerne norsk og svensk bliver nærmest usynlige, og videnskabsteori bliver betragtet som enten en redskabsdiciplin eller en autonom disciplin. Middelalder er så fjern i debatten om litteratur og sprog, at udvælgelsen af interviewpersoner foregik som et spørgsmål om, at vi som forskere "tog os sammen" til at opsøge en studerende med speciale inden for denne disciplin.

Bliver der tale om både forskningsbaseret undervisning og undervisningsbaseret forskning vil de studerende måske i højere grad motiveres til at være medstuderende og aktive deltagere i planlægningen af undervisningen. Så vidt jeg kan se fordrer sådanne processer, at der skabes variationer i undervisningen, således at overbliksgivende forelæsninger eksempelvis veksler med projektforløb med tid til fordybelser.

Skolegørelsen kan eksempelvis blive respekteret som en måde at give de studerende overblik $\mathrm{i}$ form af forelæsninger og give dem en første hjælp til at prioritere stoffet og til at bruge universitetsbibliotekerne. Selvstændighed kan varetages i holdundervisning med studenteroplæg, der involverer flere studerende end oplægsholderne og underviseren (Knudsen 1999, 2000b).

Skolegørelsen i samspil med selvstændighed kan give en større integration mellem disciplinerne og inden for den enkelte disciplin. På nordisk kan sprog og specielt sproganalyse groft taget siges negativt at underbygge skolegørelsen, idet den lægger op til reproducerende videnstilegnelse og til at være en redskabsdisciplin, hvor sproget mere bliver et middel end et forskningsudfordrende område. Litteratur og specielt litteraturhistorie giver elementer til selvstændigheden, idet de studerende her siger, at de af flere undervisere bliver sat i gang med udfordrende studenteroplæg.

Hvis de kvindelige studerende i højere grad skal motiveres til at fortsætte studierne på nordisk, så de kommer ud med en ud- 
dannelse, der er baseret på både forskning og undervisning, så skal teorierne gøres mere inspirerende, engagerende og anvendelige undervejs i studiet. De kvindelige studerende på grund- og bacheloruddannelsen bliver med et par enkelte undtagelser ikke motiverede af de teorier, som de præsenteres for. Stærkest udtrykker en af de kvindelige studerende, der vil forlade studiet det, da hun siger, at hun ikke orker at høre mere om teorier af Derrida. På overbygningsuddannelsen har en kvindelig studerende hos sin vejleder forhandlet sig frem til at inddrage denne teoretiker $\mathrm{i}$ mindst muligt omfang i sit speciale.

Men også en mandlig studerende på grund- og bacheloruddannelsen, der kan være en potentiel ph.d.-studerende udtaler sig med distance til - om end ikke til Jacques Derrida - så den dekonstruktivisme, som Derrida repræsenterer. Han ønsker sig flere og mere nuancerede teorier og metoder på nordisk.

Flere af de kvindelige studerende og et par mandlige studerende fordrer en løsning og rigtige svar i undervisningen. Dette krav kan negativt udlægges som en skolegørelse af studiet i retning af en pragmatisk holdning til undervisningens brugbarhed her og nu. Men det kan også fortolkes positivt, som de studerendes ønsker om at have noget at tage stilling til, som de selvstændigt kan vælge ud fra.

\section{AFSLUTNING}

Som Patti Lather skriver om det postmoderne samfund, sådan kan nordisk og dets studerende i slutningen af halvfemserne siges at være fyldt med paradokser og usikkerhed. Men sådanne paradokser og usikkerhed kan også anskues som mangfoldig-, flertydig- og flerstemmigheder, der udfordrer til at gøre fløjene mindre bundet til et hierarki med oppe-nede, til status med hensyn til forskning-undervisning og litteratursprog samt til magtstilling-usynliggørelse af eksempelvis litteratur-kultur og medier.
De studerende på overbygnings-, grundog bacheloruddannelsen gør faget og fagligheden på nordisk varieret, dynamisk og udfordrende. De gør faget i tale og tavshed i forskellige situationer. Men spørgsmålet er, om de bliver set og ser sig selv i de mange kompetenceudfoldelser, der ligger i de positioner, som de gennemgår undervejs i studiet? Nogle forlader studiet; men hvem ud over de nærmeste studerende i deres læsegrupper ved, hvorfor de forlader studiet? Hvordan opfordres de potentielle ph.d.studerende? Skal midtergruppen af potentielle undervisere i blandt andet gymnasiet blot uddannes som måske egnede og andenrangs undervisere uden opmærksomhed på forskningsdimensionerne i studiet?

\section{Noter}

1. Interviewene er foretaget i nævnte rækkefølge. Læsninger i interviewene udkommer i bøgerne Konsblik - på forskerrekruttering i universitetsuddannelser, red. Kirsten Reisby, Danmarks Lærerhøjskole 1999 og i Kønsblik - på grund- og bacheloruddannelsen $i$ universitetsuddannelser, Danmarks Lærerhøjskole 2000 (efterår).

Udgivelserne er led i et forskningsprojekt om Kønsbarrierer i de højere uddannelser og forskningen, der løber fra 1996-2001, og projektet er støttet af forskningsrådene. Se også artiklen af Kirsten Reisby i dette nummer.

2. Hun refererer til Roland Barthes, Jacques Derrida, Michel Foucault og Jacques Lacan. Oversættelserne er i dette afsnit mine.

3. Eksempelvis spørger hun med reference til Sandra Harding: “... hvad gør den mest indflydelsesrige feministiske forskning så magtfuld?” (Lather 1992, 92).

4. Ud fra Institutnøglen i september $1998 \mathrm{er} \mathrm{der}$ ansat en professor, seks lektorer, fire adjunkter og fire ph.d.-stipendiater inden for litteratur og en professor, fem lektorer, ingen adjunkter og en ph.d.-stipendiat inden for sprog. Af disse er der ingen kvindelige professorer, to kvinder er lektorer, en kvinde er adjunkt og to kvinder er ph.d.-stipendiat.

5. Inden for litteratur er der ud fra Institutnoglen i september 1998 ansat 18 mænd og otte kvinder heraf er en mand professor, fem mænd og en kvinde lektorer, tre mænd og en kvinde adjunkter, tre 
mænd og en kvinde ph.d.-stipendiat, to mænd og fire kvinder amanuenser og fire mænd og en kvinde er studenterundervisere.

6. Interviewet er foretaget af Susanne V. Knudsen og Anne-Mette Kruse d. 3. marts 1999.

\section{REFERENCER}

- Bruner, Jerome (1998): Uddannelseskulturen.

Munksgaard, København.

- Harding, Sandra (1987) (red.): Feminism and

Methodology. University Press, Bloomington.

- Knudsen, Susanne V. (1999): Normer og nicher - stemmer i rummene i og med undervisning og læring på en højere uddannelsesinstitution, in Mads Hermansen og Birgitte Tufte (red.): Forskning i laringsprocesser. Akademisk Forlag, København.

- Knudsen, Susanne V. (2000a): Korsveje og krydsende positioner - hvad gør de studerende med fag og faglighed på nordisk, grund- og bacheloruddannelsen, in Kønsblik - på grund-og bacheloruddannelsen i universitetsuddannelser. Danmarks Lærerhøjskole, København (kommer i efteråret 2000).

· Knudsen, Susanne V. (2000b): Undervisningsrummets stemmer - observationer af narrativ dramatiske og udramatiske konstruktioner i undervisningen på nordisk, grund- og bacheloruddannelsen, in Konsblik - på grund-og bacheloruddannelsen $i$ universitetsuddannelser. Danmarks Lærerhøjskole, København (kommer i efteråret 2000).

- Knudsen, Susanne V. (2000c): Kan græsset blive for grønt? - forskning med og i kvalitative data og $\mathrm{køn}$, in Kønsblik-pågrund-og bacheloruddannelsen $i$ universitetsuddannelser. Danmarks Lærerhøjskole, København (kommer i efteråret 2000). - Lather, Patti (1991): Getting Smart. Feminist Research and Pedagogy With/In Postmodern. Routledge, New York og London.

- Lather, Patti (1992): Critical Frames in Educational Research: Feminist and Poststructural Perspectives, in Theory and Practice, vol. XXXI, no.2.

- Reisby, Kirsten, red. (1999): Kønsblik - på forskerrekruttering i universitetsuddannelser. Danmarks Lærerhøjskole, København.
- Rittenhofer, Iris (1995): Om kønsskifte og kønnede professioner, in GRUS nr. 47. Ålborg Universitet, Aalborg.

- Selvevaluering 1996. Aarhus Universitet, Århus. - Søndergaard, Dorte Marie (1996): Tegnet på kroppen. Museum Tusculanums Forlag, København.

- Vandfanget, okt. 1998, Nordisk Institut, Aarhus Universitet, Århus.

\section{SUMMARY}

The article interprets professionalism and gender in mothertongue studies in higher education and research. The interpretation is based on a close reading of interviews with students who are writing their M.A. theses and with students who are in their second year. Opinions on academic content and approach divide the students, who are writing their M.A. theses, into two groups: some students' pronouncements are accepting and general, while others are critical and specific in what they say. The opinions on teaching and research divide the students, who are on their second year, into groups, where few want more research in their learning, whereas most of the students are unaware of research in the teaching. They prefer to learn to teach as professionals outside the university. Some of the women can tell how their choices to teach outside the university are despised in mothertongue studies in higher education. Theoretically and methodologically the author of this article is inspired by social constructivists (Rittenhofer 1995; Bruner 1998; Søndergaard 1996) and thinking beyond binarities by poststructuralism and postfeminist theories (Lather 1991, 1992; Søndergaard 1996).

Susanne V. Knudsen, Dr.Phil., Lektor, Danmarks Lærerhøjskole 